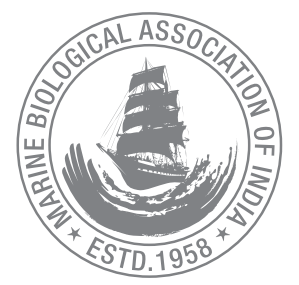

\title{
Rediscovery of the deep sea shrimp Glyphocrangon investigatoris Wood- Mason and Alcock, 1891 from Indian waters
}

\author{
S. Lakshmi Pillai* and P. Thirumilu \\ Central Marine Fisheries Research Institute, P.B. No. 1603, Kochi - 682018, India. \\ *Correspondence e-mail: slakshmipillai@rediffmail.com
}

Received: 09 Dec 2011, Accepted: 15 May 2013, Published: 30 May 2013 Short Communication

\begin{abstract}
Details on the deep sea shrimp Glyphocrangon investigatoris caught off Nagapattinam and landed at Chennai Fisheries Harbour is reported here. This species was first recorded by the Investigator expedition from Bay of Bengal and later from Porto Novo. This is the first record from regular trawl fishery. As the species is reported here more than a century after its first description from India, the distinct morphological features is presented along with the colour photographs of the specimen.
\end{abstract}

Keywords: Deep sea shrimp, Glyphocrangon investigatoris, tubercles, Indian waters.

\section{Introduction}

The exploratory survey by the Royal Indian Marine Survey ship 'Investigator' resulted in the discovery of innumerable marine decapod crustaceans from Indian waters. Glyphocrangon investigatoris Wood-Mason and Alcock, 1891 was one among them, frequently obtained from depths of 145 to 410 fathoms in the Bay of Bengal (Alcock and Anderson, 1894). Later McArdle (1901) reported the same species caught off Porto Novo from 300 fathoms along with other deep sea crustaceans. Alcock (1901) has provided the description of the species collected by the 'Investigator'. After the reports from the Investigator expeditions there is no information regarding this species from the region. The introduction of commercial deep sea trawl operations in the country in recent years led to, record of many new species and rediscovery of several crustacean species, recorded earlier by the exploratory surveys. G. investigatoris described here, was obtained from the deep sea trawl catches off Nagapattinam, landed at the Chennai fisheries harbor along with the deep sea Pandalid shrimp Heterocarpus woodmasoni and the Nephropid lobster Nephropsis stewarti. Glyphocrangon is the only genus under the family Glyphocrangonidae. A thorough revision of the genus Glyphocrangon from Indo- West Pacific under the $G$. spinicauda group by Komai (2004) provide detailed description of all species (54 numbers including $G$. investigatoris) based on the number of arthrobranchs on the first and the second pereiopods and well developed eyes. The genus Glyphocrangon is represented by 87 species worldwide (Komai, 2011). This paper gives the first validated record of $G$. investigatoris after about a century from Indian waters. Description of the species is provided with colour photographs of female (Fig. 1) and male (Fig. 2). Komai (2004) described $G$. investigatoris based on a female specimen.

\section{Material and methods}

Male and female $G$. investigatoris (one each) were collected from the Kasimedu (Chennai) fisheries harbour on 9.1.2008 


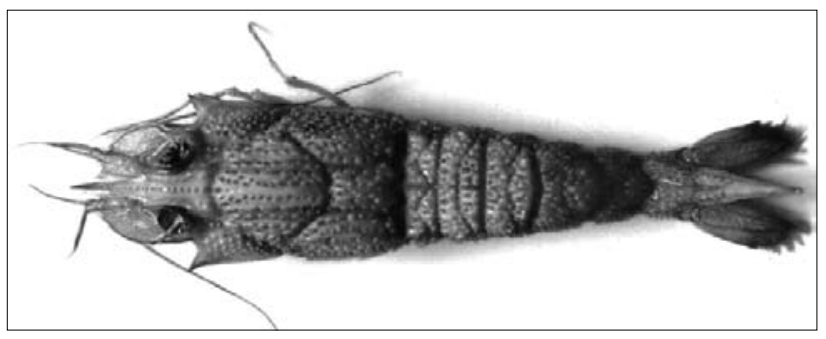

Fig.1 Dorsal view of female G. investigatoris

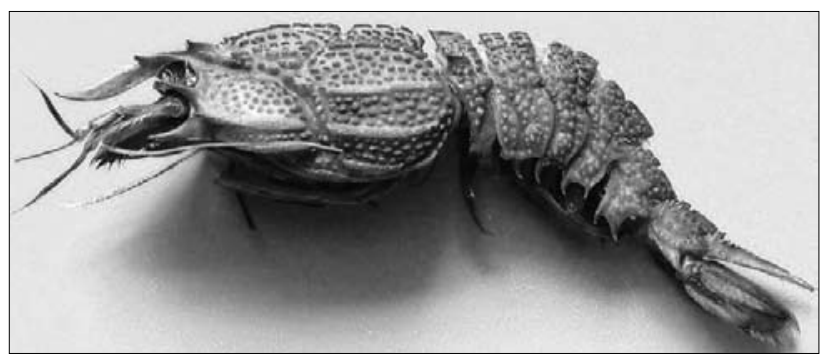

Fig.2 Lateral view of male $G$. investigatoris

and 16.3.2008 respectively, during the regular weekly sampling of the deep sea trawl catches. They were caught off Nagapattinam $\left(10^{\circ} 76.67^{\prime} \mathrm{N}, 79^{\circ} 83.33^{\prime} \mathrm{E}\right)$, south of Chennai. The specimens were identified following the keys provided by Komai (2004). They are deposited (Acc. No. ED.2.8.1.1 dated 23.08.2012) in the Marine Biodiversity Referral Museum of the Central Marine Fisheries Research Institute, Kochi, India.

\section{Results and discussion}

Glyphocrangon investigatoris Wood-Mason in Wood-Mason \& Alcock, 1891 a: 191

Glyphocrangon investigatoris Alcock \& Anderson 1894: 151 --- Wood-Mason 1894: pl. 6, Fig. 3 --- Alcock 1901: 127

Family: Glyphocrangonidae, Smith 1884, GenusGlyphocrangon A. Milne Edwards, 1881, G. investigatoris Wood-Mason and Alcock 1891.

\section{Depth of occurrence: $200-400 \mathrm{~m}$.}

Description of adult female: The female specimen measured $102 \mathrm{~mm}$ in total length (TL) and $24 \mathrm{~mm}$ in carapace length (CL). Entire carapace and abdomen except the rostrum covered with tubercles. Body is very thick and rigid. Rostrum dorsoventrally compressed, with four sharp corners and two pairs of lateral teeth, the first pair in the middle and the second one at the base. Rostrum immovably attached to remainder of carapace, is shorter compared to carapace, curved downwards with well- developed median carina. The orbital and branchiostegal spines are prominent. The carapace is almost rectangular or subcylindrical in shape with a well marked cervical groove.
Carapace and thorax firmly interlocked. The carinae present on the dorsal side of carapace are formed by tubercles and those on lateral side are ridge-like. Sub-median carina on the carapace has blunt tubercles or broad and rounded tubercles, 6 on the anterior and 4 on the posterior section. The anterior intermediate carina has 6 tubercles. Antennal and branchial spines pointed. The posterior fifth sub-lateral carina is high. The lamina of the anterior fourth lateral carina relatively small, strongly divergent and weakly curved laterally. The antennal scale is broadly oval. Upper branchial region has about 30 tubercles, all blunt, arranged in three rows. 2-3 supra-orbital tubercles present. Abdomen strongly curved dorsally. Median gastric region has a row of 10 tubercles. Anteriorly directed sub-acute tooth is present on the median carina of the first abdominal somite. Either sides of the median carina have 3-4 large tubercles. Second to fourth somite with well developed median carina, dorso-lateral carinal surface expanded. The fifth somite has a posteriorly directed tooth on the median carina. The pleura of second to fifth abdominal segments end in two recurved spine and there is only a single spine on the pleura of the sixth segment. Second abdominal somite has three rows of tubercles total 14 in number. The telson measured $14.16 \mathrm{~mm}$ in length, has three ridges (sharp dorsolateral and ventrolateral ridges) with tubercles and the middle one runs to one-fourth distance only. Appendix interna on the second pleopod of female well developed.

Description of adult male: Male specimen measured 76.3 $\mathrm{mm}$ in TL and $14.8 \mathrm{~mm}$ in CL. General body sculpture is similar to females. Dorsolateral ridge on rostrum is not as sharp as in females. The tubercles on the carapace and abdomen are less conspicuous in males compared to females. Telson measured $13.79 \mathrm{~mm}$ in length. Appendix interna on the first pleopod of males well developed.

Colour: Eyes large, spherical and pigmented with a brownish/ purplish tinge. Body is creamy white in colour with dark brown to red coloured tubercles.

Distribution: First recorded from west of Hunter's Bay, Myanmar (type locality) at depth $497 \mathrm{~m}, 19^{\circ} 35^{\prime} \mathrm{N}, 92^{\circ} 24^{\prime} \mathrm{E}$ in northern Bay of Bengal (Wood-Mason \& Alcock, 1891). The 'Investigator' recorded the species from Bay of Bengal (Alcock and Anderson, 1894) frequently and Porto Novo (McArdle, 1901). Komai (2004) described the species obtained off Sri Lanka, southern Bay of Bengal (depth 347-803 m) while reviewing the Indo-Pacific Glyphocrangon spp. The present record off Nagapattinam, on the southeast coast of India is the first from the regular trawl landing. This species is at present restricted to the Bay of Bengal region (Komai, 2004) as the specimen reported from Philippines as $G$. investigatoris (Chace, 1984) is $G$. longipes n.sp, those from Indonesia is 
G. lineata n.sp. and that from Northern Australia is G. confuse n.sp.

Remarks: There has been no published record on $G$. investigatoris from India, since its report more than a century ago based on the 'Investigator' expeditions (Alcock and Anderson, 1894; McArdle, 1901). Our specimens agree with the description of Alcock (1901) and Komai (2004) in the presence of a fine median posteriorly serrated ridge on the rostrum, presence of tubercles on the carapace and abdomen, presence of ridges and tubercules on the telson. Komai (2004) gives the number of tubercles in each region of the carapace and abdomen. In the present study the number of tubercle differ from that reported by Komai (2004) but he states that the number of tubercles may differ depending on the size of the specimen. During the 'Investigator' expedition six other species belonging to the family Glyphocrangonidae were reported from Indian waters: Glyphocrangon smithii Wood-Mason \& Alcock, 1891 - Bay of Bengal (1010 m), Glyphocrangon caeccescens Wood-Mason \& Alcock, 1891 Bay of Bengal (3197 m), Glyphocrangon gilesii Wood-Mason in Wood-Mason \& Alcock, 1891- Andaman Sea (741-914 m), Glyphocrangon priononota Wood-Mason in Wood-Mason \& Alcock, 1891- Arabian Sea (1560-1870 m), Glyphocrangon cerea Alcock \& Anderson, 1894-Lakshadweep Sea (1294 m), Glyphocrangon caecescens Wood-Mason \& Alcock, 1891West of Andaman Islands, Bay of Bengal $(1026 \mathrm{~m})$ and Glyphocrangon uniguiculata Wood-Mason in Wood-Mason \& Alcock, 1891-Arabian Sea (1353-1732 m). G. investigatoris is most similar to $G$. andamanensis, which was earlier described as a variety of $G$. investigatoris and later as its subjective synonym (Alcock, 1901; Chace, 1984) and to a lesser extent to
G. lineata n.sp of the Glyphocrangon regalis species complex. Additional records of the species in this poorly known region would be beneficial to ascertain its true distribution.

\section{Acknowledgements}

The authors are deeply indebted to Tomoyuki Komai, Department of Animal Sciences, Natural History Museum and Institute, Chiba, Japan, for confirming the identity of the species and providing reprints. They thank Dr.G.Syda Rao, Director, CMFRI and Dr.E.V.Radhakrishnan, former Head, Crustacean Fisheries Division, Kochi, for the encouragement and moral support

\section{References}

Alcock, A and A. R. Anderson. 1894. An account of a recent collection of Deep Sea Crustacea from the Bay of Bengal and Laccadive Sea. J. Asiat. Soc. of Bengal, 63, Pt.11.Natural Science. No.III, p.151

Alcock. A. 1901. A descriptive catalogue of the Indian deep sea Crustacea Decapoda Macrura and Anamola in the Indian Museum. Collected by the Royal Indian marine survey ship Investigator. Indian Museum, Calcutta, $286 \mathrm{pp}$.

Chace, F. A. Jr. 1984. The caridean shrimps (Crustacea:Decapoda) of the Philippine expedition, 1901-1910, Part 2. Families Glyphocrangonidae and Crangonidae. Smithson. Contrib. Zool., 397:1-72

Komai, T. 2004. A review of the Indo-West Pacific species of the genus Glyphocrangon A.Milne Edwards 1881 (excluding G.caeca species group) (Crustacea: Decapoda: Caridea: Glyphocrangonidae) in Marshall B. \& Richer D.Forges B.(eds), Tropical deep-sea benthos, Volume 23. Mem. Mus. Natl. Hist. Nat., 191: 375-610.

Komai, T. 2011. Further records of deep-sea shrimps of the games Glyphorangon (crustacea:Decapoda:Caridea: Cyphocrangonidae) from the Southwestern Pacific, with descriptions of two new species. Species Diversity 16: 113-135.

McArdle, A. F. 1901. Natural History Notes from the Royal Indian Marine Survey Ship 'Investigator' Commander T.I.Heming, R.N., commanding-Series III., No.5. An account of the trawling operations during the survey season of 1900-1901. On Indian deep sea trawling. Ann.Mag. Nat. Hist., 7: 519-552.

Wood Mason J and A. Alcock. 1891. Natural History notes from H.M.Indian Marine Survey Steamer "Investigator". Notes on the last season's deep sea dredging. Ann. Mag. Nat. Hist., Series. 6, 7:1-19, 186-202, 258-276, figures 1-5. 